\title{
Dispersed Knowledge With in Markets and Companies
}

\author{
Abbott Jason Haron* \\ Higher Colleges of Technology Sharjah, Sharjah, United Arab Emirates
}

\begin{abstract}
General economic thinking considerably influences Market Based Management (MBM). Opportunity-cost, marginalanalysis, creative-destruction and more, are rooted in economic thought. However, what about central planning? In the "Use of Knowledge in Society" Hayek was careful to distinguish between "central planning" by the government, which he thought was damaging and decentralized planning by individuals and organizations, which led to advantageous competition. The Market Based Management method tries to find ways to adapt the principles of a free society and market economy to advance management practice in organizations. Hayek argues that given the heavy oratorical emphasis on markets, it should come as no wonder that Market Based Management ideas have attracted attention from individuals in the varied field of organizational economics. Contrariwise, some academics in management and other social sciences express doubts, precisely because they perceive all the market based talk to be a form of monetaryimperialism that seeks to reduce all human behavior to hyper-rational self-interested enhancing.
\end{abstract}

Keywords: Market based management; Globalization; Market based management

\section{Introduction}

According to Assudani [1] "knowledge" is progressively known as being of central significance to organizations in the contemporary knowledge society. Observed evidence demonstrates that gradually knowledge-based tasks are being conducted by teams of geographically dispersed actors between markets and companies. Furthermore, firms are increasingly employing dispersed teams, since one of the benefits of dispersed teams is the ability of its members to provide diverse knowledge and expertise [2]. In spite of all this industry attention, not much understood about how to successfully cooperate to facilitate different types of knowledge-based tasks [1] the research on dispersed collaboration and knowledge management is young, the consequences of managing dispersed knowledge are less understood, and the field is still being mapped out [3].

In the age of globalization and ever-changing markets, knowledge is always found to be dispersed [4]. Each agent in the market has a sum of knowledge and it is imperfect according to [5]. It is imperfect because it is not complete and clear. Cowen and Parker[4] argued that prices are typically the factor that is known and it acts as a gauge of what is known in the market. Still these actions are unspoken knowledge. With unspoken knowledge, people are not often aware of the knowledge they retain or how valuable it can be to others [4]. Effective transfer of implicit knowledge usually necessitates extensive personal interaction and reliance. People usually are not fully conscious of the knowledge they are sharing through price signals, nor do they fully notice the knowledge that they use when they make a price choice. Nevertheless, this dispersed and implicit knowledge is not adequate in any organization. It is imperative for managers to be able to utilize this dispersed knowledge in a suitable method [3].

\section{The Problem of Dispersed Knowledge}

When a consumer goes to market, the prices he or she finds there for products and services have been set by the complex calculus that is the sum whole of the implicit knowledge residing within the market [5]. This point of view is pervasive among a few economists, for example, Friedrich Hayek (year). Information is not focal in nature; it has the affinity of disseminating. Hayek lectured that the business sector is settled on of disconnected choices and scattered contentions [6].
Hayek's (year) research and analysis shows that globalization and virtualization are some of the major causes for the dispersion of knowledge in markets and companies. As companies grow and expand, their markets change and so do the teams working together. Every team in each geographic area has some amount of knowledge but it is not complete and this problem is known as dispersed knowledge and it can lead to organizational problems [7].

These hierarchical issues need to be controlled; authoritative focal arranging is of real significance for any association to have the capacity to control them. Focal arranging must include, gathering data from diverse zones and parts of the association and collecting it into one focal database [8]. Many organizations use Enterprise Resource Planning (ERP) systems to gather all of its informational resources in one location and grant access to all users of the system to the same database for organizational consistency [9].

Nevertheless, this is not easy and requires enormous planning and resources. There are large amounts of knowledge that needs to be collected by organizations, and this requires more resources [10] therefore, the bigger the organization, the more the dispersed knowledge and more resources required for the collection of the dispersed knowledge. However, this is getting easier and faster with the proliferation of the World Wide Web and the increase in its speed and quality of service. In addition, many software and hardware developers are moving from stand-alone programs and application to fully online applications, which leads to faster, better and more efficient methods of collecting dispersed knowledge [11].

Minkler [5] identified hesitation as another driver by which knowledge dispersion causes management problems. Dispersed knowledge causes structural doubt within organizations; a strong form of doubt exists when a decision-maker cannot specify all relevant

*Corresponding author: Abbott Janson Haron, Higher Colleges of Technology Sharjah, Sharjah, United Arab Emirates, E-mail: abbottjharon@gmail.com

Recieved December 05, 2014; Accepted April 25, 2015; Published May 01, 2015

Citation: Haron AJ (2015) Dispersed Knowledge With in Markets and Companies J Entrepren Organiz Manag 4: 133. doi:10.4172/2169-026X.1000133

Copyright: (c) 2015 Haron AJ. This is an open-access article distributed under the terms of the Creative Commons Attribution License, which permits unrestricted use, distribution, and reproduction in any medium, provided the original author and source are credited. 
alternatives or outcomes. There, three different types of doubt-related decision situations are eminent: deterministic, stochastic, and vague situations [5]. Though the first two types are familiar, vagueness is less familiar [5] argues, although in a stochastic situation the likelihoods of uncertain events are known, under vagueness only a probability distribution for the apparent frequencies is known [5]. Uncertainty therefore results from the doubt associated with specifying which of a set of distributions is appropriate in a given situation [3].

Ambiguity is a prevalent element of real world decision making [12]. Although there is no agreement yet amongst economists about the suitable modeling of ambiguity, applying the concept of ambiguity to the analysis has already produced new and useful insights into many economic phenomena [6]. Therefore, if the problem of dispersion of knowledge is resolved, it can automatically resolve the problem of ambiguity [11].

\section{Conclusion}

After examining information about dispersed knowledge and its problems in markets and companies, we observed that dispersed knowledge could not help organizations achieve their operational objectives. The knowledge needs to be gathered and organized, subsequently it will provide complete information and help management and employees in improving the decision making and planning process. Managers need to understand that collecting dispersed knowledge will help them to understand the various strategies followed by different managers and executives in other parts of the world in and outside their organizational structure. This does not mean that the same strategies must be followed; nonetheless, they can be exploited in understanding the diversity and complexity of global business.

Some have argued that getting the right knowledge in order to make decisions is not just a question of increasing the existing information and knowledge. It is imperative to have effective communication, integration of cognitive structures, and develop understanding. Therefore, it can be concluded that not only access to disperse knowledge and integration of information is important; nevertheless, it needs to be understood and employed in an efficient fashion.

\section{References}

1. Assudani RH (2009) Dispersed knowledge work - implications for knowledge intensive firms. Journal of knowledge management 13: 521-532.

2. Becker MC (2001) managing dispersed knowledge: organizational problems managerial strategies, and their effectiveness. Journal of Management Studies 38: 1037-1051.

3. Raab KJ, Ambos B Tallman S (2014) Strong or invisible hands? - Managerial involvement in the knowledge sharing process of globally dispersed knowledge groups. Journal of World Business 49: 32-41.

4. Cowen T, Parker D (1997) Markets in the Firm: A Market-Process Approach to Management: The Institute of Economic Affairs, London, Great Britain

5. Minkler AP (1993) The Problem with Dispersed Knowledge: KYKLOS 46: 569 587.

6. Sole D, Edmondson A (2002) Situated Knowledge and Learning. British Journal of Management, 13: 17-34.

7. Khalil, EL (2002) Information, knowledge and the close of Friedrich Hayek's system. Eastern Economic Journal 28: 319-341.

8. Goswami S, Sharma NL (2009) Dispersed knowledge centres - a new paradigm for the pharmaceutical industry. Business Strategy Series 10: 209 - 220.

9. Mehrjerdi YZ (2010) Enterprise resource planning: risk and benefit analysis. Business Strategy Series 11: 308-324.

10. Cramton CD (2001) The mutual knowledge problem and its consequences for dispersed collaboration. Organization Science 12: 346-371.

11. Corso M, Martini A, Pellegrini L, Massa S, Testa S (2006) Managing dispersed workers: the new challenge in Knowledge Management. Technovation 26: 583-594.

12. Dew N, Velamuri SR, Venkataraman S (2004) Dispersed knowledge and an entrepreneurial theory of the firm. Journal of Business Venturing 19: 659-679. 